\title{
Manajemen Tempat Pengelolaan Sampah Terpadu Bantargebang dengan Konsep Collaborative Governance
}

\author{
Nabilla Larasati ${ }^{1 *}$ dan Anggraeny Puspaningtyas ${ }^{2}$ \\ ${ }^{1,2}$ FISIP Universitas 17 Agustus 1945 Surabaya \\ Email: larassbella0705@gmail.com ${ }^{1 *}$; anggraenypuspa@untag-sby.ac.id ${ }^{2}$ \\ *corresponding author
}

Keywords:

Collaboration, Management, Local Government, Local Government in province, TPST.

\begin{abstract}
The purpose of this research is to know the collaboration between carried out between the DKI Jakarta Provincial Government and The Bekasi Government in managing garbage in Bantargebang (TPST) and also to analyse the implementation of environmental preservation and disaster prevention using the concept of Collaborative Governance carried out by the DKI Jakarta Provincial Government and Bekasi Government written in the Cooperation Agreement (PKS) between them. The authors uses qualitative method of literature study, and obtain data based on previous research. The authors choose Edward III Theory. Based on the implementation policy of Edward III authors getting a result collaboration in the treaty of change (addendum) treaty collaboration between the DKI Jakarta Provincial Government and Bekasi Government number 25 of 2016 and Number 44 of 2014. The purpose of this collaboration to increase function Bantargebang TPST Bekasi City as a final banishment processing that will do with the application of modern garbage processing is eco-friendly technology. Budgeting for the TPST management is obtained from receiving payments for the disposal of Second Party waste based on the agreement of the parties, accepting proposals for proposals or financial assistance activities from the Second Party related to compensation funds for management of Bantargebang Bekasi City TPST, receiving accountability reports from the Second Party for the implementation of the program / financial assistance activities related to compensation funds for the management of Bantargebang TPST Bekasi City in accordance with the laws and regulations, because in Edward III theory the context of the resource also contains what authorities are entitled to have and the agreement of both parties, the authority already exists in the Bantargebang TPST Addendum. Information that has been done by the DKI Jakarta Provincial Government and Bekasi Government to implement policies and fulfill sources related to the implementation of the program has been carried out, for example by conducting an outreach to the people of DKI Jakarta related to the program to be carried out, namely waste reduction. The facilities at Bekasi City Bantargebang TPST are quite adequate, such as the washing of garbage trucks, the washing of garbage trucks is opened 24 hours and there are no operating hours restrictions. Most of the area in Bantargebang is used to accommodate various types of waste, the other $20 \%$ is used for public facilities such as offices and public parks. The Bantargebang area is the only area currently used as a waste collection facility. But, this interzonal collaboration hasn't involve the private yet, while the private has a very important to conservation preservation and disaster prevention caused by garbage. The authors have a recommendation to the government, the government needs to do collaboration with private to garbage management in Bantar Gebang TPST and maintain good relationships between them, in which coordination with ease.
\end{abstract}


Penelitian ini bertujuan untuk mengetahui kerjasama yang dilakukan antara Pemerintah Provinsi DKI Jakarta dengan Pemerintah Kota Bekasi dalam mengelola sampah di Tempat Pengelolaan Sampah Terpadu (TPST) Bantar Gebang serta menganalisis implementasi pelestarian lingkungan dan pencegahan bencana dengan menggunakan konsep collaborative governance yang berpedoman pada Perjanjian Kerja Sama (PKS) antara kedua belah pihak. Penulis menggunakan metode kualitatif studi literatur dan memperoleh data berdasarkan penelitian terdahulu. Edward III merupakan teori yang dipilih oleh penulis, berdasarkan teori kebijakan Edward III penulis mendapatkan hasil kerjasama antar daerah yang tertuang dalam Perjanjian Perubahan (addendum) perjanjian kerjasama antara Pemerintah Provinsi DKI Jakarta dengan Pemerintah Kota Bekasi No. 25 Tahun 2016 dan No.444 Tahun 2016. Tujuan dilakukannya kerjasama ini adalah untuk meningkatkan fungsi TPST Bantargebang Kota Bekasi sebagai tempat pengelolaan akhir yang akan dilakukan dengan penerapan teknologi pengolahan sampah modern serta ramah lingkungan. Penganggaran untuk pengelolaan TPST ini didapatkan dari penerimaan pembayaran atas pembuangan sampah pihak kedua berdasarkan kesepakatan para pihak, menerima usulan proposal atau kegiatan bantuan keuangan dari pihak kedua terkait dengan dana kompensasi pengelolaan TPST Bantargebang Kota Bekasi, menerima laporan pertanggung jawaban dari pihak kedua atas pelaksanaan program/kegiatan bantuan keuangan terkait dana kompensasi pengelolaan TPST Bantargebang Kota Bekasi sesuai dengan peraturan perundang-undangan, karena dalam teori Edward III konteks sumber daya berisikan pula tentang kewenangan apa saja yang berhak ada dan persetujuan kedua belah pihak, kewenangan tersebut pun sudah ada dalam Addendum TPST Bantargebang. Informasi yang dilakukan Pemerintah Provinsi DKI Jakarta dan Pemerintah Kota Bekasi untuk mengimplementasikan kebijakan dan pemenuhan sumber-sumber terkait dalam pelaksanaan program sudah dilakukan contohnya dengan melakukan sebuah sosialisasi kepada masyarakat DKI Jakarta terkait program yang akan dilakukan yaitu pengurangan sampah. Fasilitas-fasilitas di TPST Bantargebang Kota Bekasi pun cukup memadai seperti pencucian truk sampah, pencucian truk sampah ini pun dibuka 24 jam dan tidak ada batasan jam operasional. Sebagian besar, luas di Bantargebang digunakan untuk menampung berbagai jenis sampah, 20\% lahan yang lain digunakan untuk fasilitas umum seperti kantor dan tamantaman publik. Wilayah Bantargebang adalah satu-satunya wilayah yang saat ini digunakan sebagai penampungan sampah. Namun, kerjasama antar daerah ini belum melibatkan pihak swasta, padahal pihak swasta mempunyai peran sangat penting dalam pelestarian lingkungan dan pencegahan bencana alam yang disebabkan oleh sampah. Penulis merekomendasikan pemerintah perlu melakukan kerjasama dengan pihak swasta dalam pengelolaan sampah yang

Kata Kunci:

Kerjasama, Pengelolaan, Pemkot, Pemprov, TPST. ada di TPST Bantargebang serta menjaga hubungan yang baik antara kedua belah pihak, sehingga koordinasi yang dilakukan berjalan dengan mudah.

Copyright $(02020$ Channel Jurnal Komunikasi. All right reserved.

\section{PENDAHULUAN}

Indonesia menempati posisi ke-4 dengan 269 juta jiwa atau 3,49\% dari total populasi dunia, ini mengatakan bahwa Indonesia merupakan salah satu negara terpadat penduduknya, berdasarkan data Worldometers (diakses melalui www. databoks.katadata.co.id. pada tanggal 2 November 2019). Berkaitan dengan ini bila volume penduduk semakin padat dalam suatu wilayah, maka bertambah pula volume sampah di wilayah tersebut. Sampah merupakan masalah krusial yang ada di Indonesia dan juga menjadi masalah sosial, ekonomi, dan budaya. Hampir beberapa daerah di Indonesia mengalami hambatan dalam pengelolaan sampah. Salah satu daerah yang mendapat kendala tersebut adalah Bantargebang Bekasi, Jawa Barat yang mendapatkan kiriman sampah dari DKI Jakarta.

Menurut laman berita Kompas (diakes melalui www.kompas.com pada tanggal 4 November 2019 ) setiap harinya Jakarta perlu 1.278 truk sampah penduduk dikarenakan Jakarta menghasilkan 7.400 ton sampah setiap harinya, dimana kecamatan di Jakarta per harinya menghasilkan rata-rata 168 ton sampah. Jika di tumpukan sampah itu setara dengan setengah Candi Borobudur dan sampah-sampah tersebut berakhir di TPST Bantargebang Bekasi. Sampah yang dihasilkan 
lebih banyak daripada sampah yang diproses, tidak heran jika area penampungan sampah kian lama kian penuh serta hanya 20\% dari jumlah sampah yang didaur ulang dan sisanya berakhir di TPA. Menurut Dinas Lingkungan Hidup DKI Jakarta, mereka memprediksikan bahwasannya Tempat Pemrosesan Akhir Sampah Terpadu (TPST) Bantar Gebang ini hanya mampu beroperasi hingga tahun 2021.

Pemerintah Provinsi (Pemprov) DKI Jakarta dan Pemerintah Kota (Pemkot) Bekasi melakukan kerja sama untuk pengelolaan TPST Bantargebang, dasar hukum tertuang dalam kerjasama antara Pemerintah Provinsi Daerah Khusus Ibukota Jakarta dengan Pemerintah Kota Bekasi Nomor 96 Tahun 1999 dan Nomor 168 Tahun 1999 tentang pengelolaan sampah dan Tempat Pembuangan Akhir (TPA) sampah di Kecamatan Bantargebang, Kota Bekasi dan perjanjian perubahan (addendum) perjanjian kerjasama antara Pemprov DKI Jakarta dengan Pemkot Bekasi tentang Peningkatan Pemanfaatan Lahan Tempat Pembuangan Akhir (TPA) Sampah menjadi Tempat Pengelolaan Sampah Terpadu (TPST) Bantargebang Kota Bekasi sesuai dengan peraturan No. 4 Tahun 2017 dan No.224 Tahun 2017.

Dari segi penganggaran untuk pengelolaan TPST ini diperoleh dari penerimaan pembayaran atas pembuangan sampah pihak kedua berdasarkan kesepakatan para pihak, menerima usulan proposal atau kegiatan bantuan keuangan dari pihak kedua terkait dengan dana kompensasi pengelolaan TPST Bantargebang Kota Bekasi, menerima laporan pertanggung jawaban dari pihak kedua atas pelaksanaan program/kegiatan bantuan keuangan terkait dana kompensasi pengelolaan TPST Bantargebang Kota Bekasi sesuai dengan peraturan perundang-undangan, karena dalam teori Edward III konteks sumber daya berisikan pula tentang kewenangan apa saja yang berhak ada dan persetujuan kedua belah pihak, kewenangan tersebut pun sudah ada dalam Addendum TPST Bantargebang.

Informasi yang dilakukan Pemerintah Provinsi DKI Jakarta dan Pemerintah Kota Bekasi untuk mengimplementasikan kebijakan dan pemenuhan sumber-sumber terkait dalam pelaksanaan program sudah dilakukan contohnya dengan melakukan sebuah sosialisasi kepada masyarakat DKI Jakarta terkait program yang akan dilakukan yaitu pengurangan sampah. Fasilitas-fasilitas di TPST Bantargebang Kota Bekasi pun cukup memadai seperti pencucian truk sampah, pencucian truk sampah ini pun dibuka 24 jam dan tidak ada batasan jam operasional. Sebagian besar luas di Bantargebang digunakan untuk menampung berbagai jenis sampah, 20\% lahan yang lain digunakan untuk fasilitas umum seperti kantor dan taman-taman publik. Wilayah Bantargebang adalah satu-satunya wilayah yang saat ini digunakan sebagai penampungan sampah dan belum ada wilayah yang lain sebagai pengganti TPST Bantargebang.

Berdasarkan penelitian yang dilakukan oleh Winahyu, Hartoyo, dan Syaukat, 2013 yang berjudul Strategi Pengelolaan Sampah pada Tempat Pembuangan Akhir Bantar Gebang, Bekasi. (melalui analisis SWOT). Jika dilihat dari segi analisis SWOT maka harus menganalisis berbagai strategi, jika menggunakan analisis berdasarkan Edward III bisa dilihat secara lebih kompleks dan secara terstruktur. Pada analisis SWOT penelitian sebelumnya didapatkan peningkatan anggaran dan perbaikan teknologi di bidang persampahan, dirasa sudah mencukupi untuk pengelolaan sampah di TPA Bantar Gebang, tetapi dalam analisis ini tidak dijelaskan dari manakah anggaran itu didapat.

Penelitian yang dilakukan oleh Kholilurrohman, Adiyasha, dan Tanriajeng, 2019 dalam artikel yang dipaparkan pada Temu Admi 2019. Penelitian ini berjudul Kerjasama Antara Pemerintah Provinsi DKI Jakarta dan Pemerintah Kota Bekasi dalam Mengelola TPST Bantargebang. Penelitian ini mengacu pada teori Kerjasama antar daerah oleh Pratikno, jika dilihat dari segi teori, kelemahan teori ini tidak menggambarkan secara kompleks. Karena yang dibahas hanya dari segi kerjasama antar daerah saja dan tidak ada pembahasan mengenai TPST Bantargebang secara luas.

Adapun tujuan dari penelitian ini adalah untuk (a) mengetahui kerjasama yang dilakukan antara Pemerintah Provinsi DKI Jakarta dengan Pemerintah Kota Bekasi dalam mengelola sampah di TPST Bantargebang, (b) menganalisis implementasi pelestarian lingkungan dan pencegahan bencana menggunakan konsep collaborative governance yang dilakukan Pemerintah Provinsi DKI Jakarta dan Pemerintah Kota Bekasi.

\section{METODE PENELITIAN}

\section{A. Tipe Penelitian}

Tujuan penelitian sebagaimana telah dijabarkan sebelumnya adalah untuk mengetahui dan menganalisis kerjasama antara kedua belah pihak dalam mengelola sampah di TPST Bantar Gebang dengan menggunakan konsep collaborative governance guna pelestarian lingkungan dan pencegahan bencana. Untuk mencapai tujuan tersebut penelitian "deskriptif kualitatif" lebih tepat dilakukan. Penelitian tipe ini berusaha tidak saja menggambarkan atau mendeskripsikan temuan fenomena, data dan fakta hasil temuan penelitian lapangan, tapi juga berusaha memberikan makna apa yang terkandung dalam fenomena, data dan fakta hasil temuan penelitian lapangan.

\section{B. Lokus dan Situs Penelitian}

Berhubungan dengan hal tersebut maka yang menjadi lokus penelitian adalah Dinas Lingkungan Hidup Provinsi DKI Jakarta sedangkan situs penelitian adalah Tempat Pembuangan Sampah Terpadu (TPST) Kota Bekasi. 


\section{Fokus Penelitian}

Penelitian deskriptif kualitatif senantiasa menghendaki fokus sebagai batas penelitian. Sehubungan dengan hal tersebut, yang menjadi fokus penelitian adalah menurut Edward ada empat teknik analisis yang perlu diperhatikan dan berpengaruh yaitu :

1. Komunikasi, indikator ini mencakup ukuran dan tujuan kebijakan yang harus dipahami oleh yang bertanggung jawab dalam pengelolaan TPST Bantargebang dan pelestarian lingkungan dan pencegahan bencana;

2. Sumber Daya, dalam indikator sumber daya mencakup beberapa hal yang terkait dengan pelaksanaan program;

3. Disposisi, lebih mengarah pada respon pelaksana kebijakan dan memutuskan suatu kebijakan diterima atau ditolak;

4. Struktur Birokrasi, menjalin kesesuaian dalam hal karakteristik, norma-norma dan pola-pola hubungan antara Pemerintah Provinsi DKI Jakarta dengan Pemerintah Kota Bekasi.

\section{Sumber Data}

Penelitian ini memiliki sumber data dari data sekunder yaitu berasal dari kajian pustaka dan jurnal penelitian yang telah ada. Setidaknya dalam penelitian ini penyusun menggunakan data sekunder untuk menunjang informasi dan data yang penyusun butuhkan. Data sekunder merupakan data yang diperoleh dari sumber data yang telah mengalami pengolahan data dan telah mengandung informasi. Penelitian ini menelaah buku, penelitian-penelitian yang dilakukan serta dokumen-dokumen lain yang membahas tentang Kerjasama Pemerintah Provinsi DKI Jakarta dengan Pemerintah Kota Bekasi dalam pengelolaan sampah yang ada di Bantargebang dan pelestarian lingkungan serta pencegahan bencana di wilayah Bantargebang.

\section{E. Teknik Pengumpulan Data}

Bungin (2003: 42), menjelaskan metode pengumpulan data adalah "Dengan cara apa dan bagaimana data yang diperlukan dapat dikumpulkan sehingga hasil akhir penelitian mampu menyajikan informasi yang valid dan credible". Sementara, Arikunto (2002:136), berpendapat bahwa "metode penelitian adalah berbagai cara yang digunakan peneliti dalam mengumpulkan data penelitiannya". Peneliti melakukan pengumpulan data dengan mereview dan mengkontruksi penelitian-penelitian empiris yang pernah dilakukan dari penelitian terdahulu dan sumber-sumber dokumen yang dapat dipertanggungjawabkan.

\section{F. Instrumen Penelitian}

Instrumen penelitian menurut Arikunto (2006: 149) adalah merupakan alat bantu bagi peneliti dalam mengumpulkan data. Instrumen yang digunakan oleh peneliti dalam hal ini adalah literatur, dokumen, jurnal, dan penelitian-penelitian yang pernah dibuat.

\section{G. Teknik Analisis Data}

Analisis data menurut Patton (Moleong, 2000: 103) merupakan proses mengatur urutan data, mengorganisasikannya ke dalam suatu pola, kategorisasi, dan satuan uraian dasar. Bertumpu pada konsep ini, teknik analisis data yang digunakan dalam penelitian ini adalah teknik analisis data kualitatif studi literatur, yakni melakukan analisis dan mendeskripsikan secara kualitatif dan mencari dan memberi makna atas data hasil temuan lapangan sesuai dengan teori dan konsep yang dipijak sesuai studi literatur yang menjadi acuan.

\section{HASIL DAN PEMBAHASAN}

Volume sampah yang kian lama kian meningkat mengharuskan pemerintah untuk memacu lebih cepat dalam mengelola sampah. Kota-kota besar Indonesia adalah salah satu penyumbang sampah terbanyak. Contohnya saja DKI Jakarta, menurut plt Kepala Dinas Lingkungan hidup DKI Jakarta Andono Warih dalam wawancaranya dengan Kompas, mengatakan bahwa "DKI Jakarta tiap harinya memproduksi 7.500 ton, jika di tumpukan sampah itu sebesar Candi Borobudur. Sampah 7.500 ton tersebut berasal dari sampah rumah tangga. Riset menyatakan bahwa 60 persen dari pemukiman, dan 29 persen dari kawasan komersial seperti hotel, serta 11 persen berasal dari fasilitas umum." Sampahsampah tersebutlah dilarikan ke TPST Bantargebang Kota Bekasi, dari tipping fee sampah yang masuk TPST, sampah Jakarta ini diangkut menggunakan armada angkutan sampah, dimana ini memberikan keuntungan berupa penyerapan tenaga kerja, tetapi juga menyebabkan dampak lingkungan berupa bau bagi wilayah yang dilalui armada tersebut. Jalan yang dilalui armada tersebut seperti kelima wilayah di Jakarta melalui jalan alternatif Cibubur, jalan raya Cileungsi, Jalan Raya Narogong dengan jarak tempuh antara 15-50 KM.

Pemerintah Provinsi DKI Jakarta dan Pemerintah Kota Bekasi melakukan kerja sama untuk pengelolaan TPST Bantargebang, dasar hukum tertuang dalam kerjasama antara Pemerintah Provinsi Daerah Khusus Ibukota Jakarta dengan Pemerintah Kota Bekasi Nomor 96 Tahun 1999 dan Nomor 168 Tahun 1999 tentang pengelolaan sampah dan Tempat 
Pembuangan Akhir (TPA) sampah di Kecamatan Bantargebang, Kota Bekasi dan perjanjian perubahan (addendum) perjanjian kerjasama antara Pemprov DKI Jakarta dengan Pemkot Bekasi tentang Peningkatan Pemanfaatan Lahan Tempat Pembuangan Akhir (TPA) Sampah menjadi Tempat Pengelolaan Sampah Terpadu (TPST) Bantargebang Kota Bekasi No. 4 Tahun 2017 dan No.224 Tahun 2017.

Penelitian yang dilakukan oleh Winahyu, Hartoyo, Syaukat (2013) yang berjudul Strategi Pengelolaan Sampah pada Tempat Pembuangan Akhir Bantargebang, Bekasi. Jika dilihat dari segi analisis SWOT maka harus menganalisis berbagai strategi, jika menggunakan analisis berdasarkan Edward III bisa dilihat secara lebih kompleks dan juga secara terstruktur. Pada analisis SWOT penelitian sebelumnya didapatkan peningkatan anggaran dan perbaikan teknologi di bidang persampahan, dirasa sudah mencukupi untuk pengelolaan sampah di TPA Bantargebang, tetapi dalam analisis ini tidak dijelaskan dari manakah anggaran itu diperoleh. Sedangkan dalam teori Edward bisa dijelaskan melalui konteks sumber daya dimana anggaran untuk pengelolaan TPST Bantargebang ini didapatkan pula dari penerimaan pembayaran atas pembuangan sampah pihak kedua berdasarkan kesepakatan para pihak, menerima usulan proposal/kegiatan bantuan keuangan dari pihak kedua terkait dengan dana kompensasi pengelolaan TPST Bantargebang Kota Bekasi, menerima laporan pertanggung jawaban dari pihak kedua atas pelaksanaan program/kegiatan bantuan keuangan terkait dana kompensasi pengelolaan TPST Bantargebang Kota Bekasi sesuai dengan peraturan perundang-undangan, karena dalam teori Edward III konteks sumber daya berisikan pula tentang kewenangan apa saja yang berhak ada dan persetujuan kedua belah pihak, kewenangan tersebut pun sudah ada dalam Addendum TPST Bantargebang. Dengan adanya kewenangan seperti itu diharapkan dapat menjamin bahwa program dapat diarahkan untuk mencapai tujuan yang diinginkan yaitu untuk menangani permasalahan pengangkutan dan pembuangan sampah serta untuk mengurangi tingkat pencemaran lingkungan di TPST Bantargebang Kota Bekasi.

Penelitian yang dilakukan oleh Kholilurrohman, Adiyasha, dan Tanriajeng (2019) dalam artikel yang dipaparkan pada Temu Admi 2019, berjudul Kerjasama Antara Pemerintah Provinsi DKI Jakarta dan Pemerintah Kota Bekasi dalam Mengelola TPST Bantar Gebang. Penelitian ini mengacu pada teori Kerjasama antar daerah oleh Pratikno, jika dilihat dari segi teori, kelemahan teori ini tidak menggambarkan secara kompleks. Karena yang dibahas hanya dari segi kerjasama antar daerah saja dan tidak ada pembahasan mengenai TPST Bantar Gebang secara luas.

Berdasarkan data yang penulis himpun dan melakukan perbandingan dengan penelitian sebelumnya berdasarkan studi literatur maka dapat dijabarkan melalui teori implementasi Edward III meliputi komunikasi, sumberdaya, disposisi, dan struktur birokrasi.

\section{A. Komunikasi}

Indikator komunikasi stakeholder yang terkait yaitu Pemerintah Provinsi DKI Jakarta dan Pemerintah Kota Bekasi dirasa sudah memahami tanggung jawab dalam pencapaian tujuan kebijakan, dimana dapat dilihat dengan adanya kerjasama antar daerah ini yang tertuang dalam Perjanjian Perubahan (addendum) perjanjian kerjasama antara Pemerintah Provinsi DKI Jakarta dengan Pemerintah Kota Bekasi No. 25 Tahun 2016 dan No.444 Tahun 2016, dalam Pasal 2 tertuang maksud dan tujuan dilakukannya kerja sama yaitu untuk meningkatkan fungsi TPST Bantargebang Kota Bekasi sebagai tempat pemrosesan akhir yang akan dilakukan dengan penerapan teknologi pengolahan sampah modern serta ramah lingkungan. Sementara tujuan dari kerjasama ini adalah untuk menangani permasalahan pengangkutan pembuangan sampai pada pemrosesan akhir sampah dari wilayah pihak pertama sebagai ibukota Negara Republik Indonesia maupun dari wilayah pihak kedua serta untuk mengurangi tingkat pencemaran lingkungan di TPST Bantargebang Kota Bekasi dan sekitarnya.

\section{B. Sumber daya}

1. Jumlah staf yang terlibat dalam pengelolaan TPST Bantargebang berdasarkan studi literatur yang penulis gunakan, perlunya jumlah personil yang ada di lapangan harus cukup memadai sesuai dengan lingkup kerjanya. Kriteria personalia minimal harus cukup memadai untuk pelayanan setiap 100 penduduk dilayani dua orang petugas, dalam pelaksanaannya jumlah penduduk yang terlayani hanya mencapai 35 persen dari jumlah penduduk yang ada di DKI dan di Kota Bekasi. karena itu perlu adanya penambahan personil karena sampai saat ini hanya terlayani 35 persen sehingga masih kekurangan pelayanan hampir 65 persen dan perlu adanya kebijakan dari pemerintah daerah dalam penambahan personil untuk pelayanan di lapangan. (Winahyu, Hartoyo, Syaukat : 2013)

2. Informasi yang dilakukan Pemerintah Provinsi DKI Jakarta dan Pemkot Bekasi untuk mengimplementasikan kebijakan dan pemenuhan sumber-sumber terkait dalam pelaksanaan program sudah dilakukan contohnya dengan melakukan sebuah sosialisasi kepada masyarakat DKI Jakarta terkait program yang akan dilakukan yaitu pengurangan sampah, contohnya Dinas Lingkungan Hidup Provinsi DKI Jakarta menggelar berbagai kegiatan memperingati Hari Peduli Sampah Nasional (HPSN) Tingkat Provinsi Tahun 2019 dengan tema DKI Nyok Kerja Bakti Berkesinambungan Guna Mewujudkan Jakarta yang Bersih, Sehat, Indah dan Asri. Pemprov DKI Jakarta senantiasa berkomitmen untuk menghadirkan lingkungan yang bersih dan bebas dari 
sampah di Ibu Kota dengan mengajak seluruh lapisan masyarakat, komunitas-komunitas yang bergerak dalam pengelolaan sampah, serta para pemangku kepentingan untuk berkolaborasi dalam mewujudkan hal tersebut, juga turut mengkampanyekan kegiatan pengurangan sampah di seluruh wilayah DKI Jakarta. (diakses melalui www.Infopublik.id pada tanggal 5 November 2019)

3. Adanya kewenangan yang dimiliki Pemerintah Provinsi DKI Jakarta dan Pemerintah Kota Bekasi dalam pengelolaan sampah di TPST Bantargebang. Kewenangan yang ada meliputi pada pihak pertama yaitu melakukan pengangkutan dan pengelolaan sampah rumah tangga dari pihak pertama dan diarahkan ke pihak kedua, mendapatkan fasilitas keamanan dalam hal pengangkutan sampah rumah tangga atau sejenisnya menuju lokasi pihak kedua, mendapatkan fasilitas keamanan pengelolaan TPST Bantargebang Kota Bekasi tanpa hambatan dari pihak kedua atau pihak manapun, bersama-sama pihak kedua menjamin pengelolaan dan pemanfaatan TPST Bantargebang Kota Bekasi berjalan dengan lancar, menerima pembayaran atas pembuangan sampah pihak kedua berdasarkan kesepakatan para pihak, menerima usulan proposal/kegiatan bantuan keuangan dari pihak kedua terkait dengan dana kompensasi pengelolaan TPST Bantargebang Kota Bekasi, menerima laporan pertanggung jawaban dari pihak kedua atas pelaksanaan program/kegiatan bantuan keuangan terkait dana kompensasi pengelolaan TPST Bantargebang Kota Bekasi sesuai dengan peraturan perundang-undangan. (Sumber : Addendum TPST Bantargebang). Dengan adanya kewenangan seperti itu diharapkan dapat menjamin bahwa program dapat diarahkan untuk mencapai tujuan yang diinginkan yaitu untuk menangani permasalahan pengangkutan dan pembuangan sampah serta untuk mengurangi tingkat pencemaran lingkungan di TPST Bantargebang Kota Bekasi.

4. Fasilitas yang tersedia di TPST Bantargebang Kota Bekasi cukup memadai seperti pencucian truk sampah, pencucian truk sampah ini pun dibuka 24 jam dan tidak ada batasan jam operasional, karena mengingat pengangkutan sampah pun non-stop, fasilitas pencucian truk ini lebih pada membasuh truk dibanding membersihkan, karena lebih ditekankan untuk menghilangkan bau yang ada di truk sampah.

\section{Disposisi}

Respon Pemerintah Provinsi DKI Jakarta dalam pengelolaan sampah di TPST Bantargebang ini dengan memberikan bantuan keuangan atau dana kemitraan dan dana kompensasi kepada Pemerintah Kota Bekasi, bantuan ini bersifat wajib. Dua bantuan ini dilakukan guna meningkatkan fasilitas umum untuk mendukung aktivitas masyarakat DKI Jakarta dan masyarakat Kota Bekasi. Selain itu, respon Pemerintah Provinsi DKI Jakarta dalam menanggulangi sampah adalah dengan merumuskan tiga Kegiatan Strategis Daerah (KSD) untuk mengatasi permasalahan pengelolaan sampah jangka pendek maupun jangka panjang. Tiga KSD itu meliputi Pengurangan sampah di Sumber, Optimalisasi TPST Bantargebang, Pembangunan Intermediate Treatment Facility (ITF). Pengurangan sampah dilakukan dengan melalui kegiatan Sampah Tanggung Jawab (Samtama) melalui Rukun Warga (RW) Percontohan. Sosialisasi, pembinaan, pendampingan, dan fasilitas untuk membuat warga Jakarta semakin masif dalam mengurangi sampah merupakan outcome KSD Pengurangan Sampah. Sedangkan pada program optimalisasi TPST Bantargebang Pemerintah Provinsi DKI Jakarta bekerja sama dengan Badan Pengkajian dan Penerapan Teknologi (BPPT) membangun Pembangkit Listrik Tenaga Sampah (PLTSa) yang sekarang sudah beroperasi. Pengolahan sampah dengan teknologi termal ini menggunakan sampah lama dari landfill (landfill mining) untuk dijadikan bahan bakar alternatif (Refused Derived Fuel) industri semen. Bahan bakar alternatif dari sampah ini setara dengan nilai kalor batubara muda. Pada program Pembangunan Intermediate Treatment Facility (ITF) adanya ITF TPST Bantargebang hanya akan menampung residu pengolahan sampah di dalam kota. "Saat ini proses eksekusi KSD tersebut sudah berjalan. Salah satunya, kita dapat melihat, pengelolaan TPST Bantargebang sudah jauh lebih baik dalam 1-2 tahun terakhir," tegas Anies dalam wawancaranya bersama kompas dalam artikel berjudul Strategi Pemerintah Provinsi DKI dalam mengelola Sampah Jakarta. Dengan KSD diharapkan, sampah rumah tangga dan sejenisnya di DKI berkurang hingga 30 persen pada 2025.

\section{STRUKTUR BIROKRASI}

\section{A. Kesesuaian Karakteristik}

Karakteristik yang dimiliki Kota Bekasi dan DKI Jakarta hampir memiliki kesamaan seperti halnya kedua wilayah ini memiliki penduduk yang padat, dimana banyaknya penduduk maka volume sampah di wilayah tersebut akan meningkat pula, seperti halnya di DKI Jakarta. Di Kota Bekasi sendiri memiliki sebutan 1001 mall karena banyaknya mall yang ada di Bekasi serta hotel bintang lima nya dan begitu pula dengan di DKI Jakarta. Untuk menanggulangi persampahan yang ada di kedua wilayah tersebut pada akhirnya mereka melakukan kerjasama untuk pengelolaan sampah dan TPST Bantargebang lah yang menjadi objek kerjasama kedua belah pihak. 


\section{B. Kesesuaian Norma-norma dalam penanggulangan dan pengelolaan sampah.}

\begin{tabular}{l|l} 
DKI JAKARTA & BEKASI \\
\hline $\begin{array}{l}\text { Rancangan Perubahan Peraturan Daerah No. 3 } \\
\text { Tahun 2013 tentang Pengelolaan Sampah (revisi } \\
\text { Perda DKI 3/2013); }\end{array}$ & $\begin{array}{l}\text { Peraturan Daerah Kota Bekasi No. 51 Tahun 2011 } \\
\text { Tentang Pengelolaan Sampah di Kota Bekasi. }\end{array}$ \\
$\begin{array}{l}\text { Rancangan Peraturan Gubernur Tentang } \\
\text { Lembaga Pengelolaan Sampah (Rapergub LPS) }\end{array}$ & $\begin{array}{l}\text { Peraturan Walikota Bekasi No. 65 Tahun 2018 } \\
\text { Tentang Kebijakan dan Strategi Pemerintah Kota } \\
\text { Bekasi dalam Pengelolaan Sampah Rumah Tangga } \\
\text { dan Sampah Sejenis Sampah Rumah Tangga. }\end{array}$ \\
$\begin{array}{l}\text { Rancangan Peraturan Gubernur tentang Sarana } \\
\text { dan Prasarana Pengelolaan Sampah (Rapergub } \\
\text { Sarpras) }\end{array}$ &
\end{tabular}

Pada Peraturan Daerah DKI No 3 tahun 2013 berisikan ketentuan-ketentuan untuk mengakomodir pembangunan beberapa Intermediate Treatment Facility (ITF) di DKI Jakarta. Sedangkan pada Rancangan Peraturan Gubernur LPS merupakan delegasi dari Peraturan Daerah No 2 tahun 2013, pada norma ini perlu dilakukannya pemetaan posisi LPS terhadap norma yang ada dalam Peraturan Daerah, dan Rancangan Peraturan Gubernur sarana prasarana digunakan sebagai penyeimbang antara membuka ruang bagi inovasi yang belum diatur, dengan menutup ruang kesewenangan. Pada peraturan Walikota Bekasi Peraturan Walikota Bekasi No. 65 Tahun 2018 Tentang Kebijakan dan Strategi Pemerintah Kota Bekasi dalam Pengelolaan Sampah Rumah Tangga dan Sampah Sejenis Sampah Rumah Tangga. Memuat tentang (1) arah kebijakan pengurangan dan penanganan sampah rumah tangga dan sampah sejenis sampah rumah tangga. (2) strategi, program, dan target pengurangan dan penanganan sampah rumah tangga dan sampah sejenis sampah rumah tangga.

Sedangkan, Peraturan Daerah Kota Bekasi No. 51 Tahun 2011 Tentang Pengelolaan Sampah di Kota Bekasi. Ruang lingkupnya mengacu pada (1) sampah yang dikelola berdasarkan Peraturan Daerah yang terdiri dari Sampah rumah tangga, sampah sejenis sampah rumah tangga, dan sampah plastik, (2) sampah rumah tangga sebagaimana dimaksud berasal dari kegiatan sehari -hari dalam rumah tangga, tidak termasuk tinja dan sampah spesifik, (3) sampah sejenis sampah rumah tangga sebagaimana yang dimaksud meliputi kawasan komersial, kawasan industri, kawasan khusus, fasilitas sosial, fasilitas umum, dan/atau fasilitas lainnya, (4) sampah spesifik yang dimaksud adalah sampah yang mengandung bahan beracun dan berbahaya, sampah yang mengandung limbah yang beracun dan berbahaya, sampah yang timbul akibat bencana, puing bongkaran bangunan, sampah yang secara teknologi belum dapat diolah, sampah yang timbul secara periodik. Dari hal tersebut dapat ditarik kesimpulan bahwasanya kedua belah pihak bekerjasama untuk mengelola sampah dan meningkatkan kualitas lingkungan masyarakat serta meningkatkan efisiensi.

\section{Kesesuaian Pola-Pola Hubungan}

Kesesuaian pola hubungan antara Pemerintah Provinsi DKI Jakarta dengan Pemerintah Kota Bekasi dapat dilihat dari addendum kerjasama yang tertulis dan telah disepakati, mencapai tujuan dalam penanggulangan dan pengelolaan sampah hal sinergis dan saling menguntungkan terlihat, kedua belah pihak sepakat untuk terus menjalin koordinasi secara rutin demi menjaga sinergitas antar pemerintah daerah, sehingga terjadinya miss komunikasi pun dapat di minimalisir. Para kedua belah pihak tidak mungkin mempunyai kepentingan yang sepenuhnya sama, maka kejelasan transaksi atau take and give merupakan sesuatu yang harus dibuat. Kesepakatan yang diperoleh masing-masing daerah hampir sama, yaitu manfaat dari adanya TPST Bantargebang tersebut. Pemerintah Provinsi DKI Jakarta membutuhkan lahan untuk tempat pembuangan akhir dari sampah warga Ibukota sedangkan Pemerintah Kota Bekasi membutuhkan dana kemitraan untuk membangun dan menata Kota Bekasi. Pemberian yang diberikan berupa saran-saran yang diberikan ketika rapat bersama kedua belah pihak dalam menyepakati suatu keputusan dalam rangka memperkuat perjanjian kerjasama.

Penelitian ini menggunakan metode triple helix sebagai acuan untuk menganalisis implementasi pelestarian lingkungan dan pencegahan bencana menggunakan konsep collaborative governance yang dilakukan Pemerintah Provinsi DKI Jakarta dan Pemerintah Kota Bekasi. Berdasarkan data yang berhasil menyusun temukan melalui Studi literatur penulis menemukan fakta bahwa TPST Bantargebang membutuhkan suatu tindakan yang terpadu agar pengelolaan TPST dapat berlangsung optimal dan bermanfaat dari sudut pandang masing-masing stakeholder.

Pemerintah Provinsi DKI sebagai pemilik TPST Pemerintah Kota Bekasi sebagai otoritas yang memerintah di Bantargebang, selain itu fasilitas-fasilitas yang ada pada TPST Bantargebang setidaknya lebih diperbanyak dan lebih dipenuhi. Berikut hasil wawancara yang penulis dapatkan berdasarkan wawancara yang dilakukan oleh mahasiswa administrasi publik Universitas Muhammadiyah Jakarta (UMJ) berdasarkan studi literatur. Masyarakat yang dilalui oleh armada pengangkut sampah tersebut menyampaikan keluhan terhadap dampak bau tersebut. Seperti yang disampaikan oleh Kepala Sub Bagian Tata Usaha UPST DLH DKI Jakarta, yaitu “Sampah sebesar 7500 ton perhari, tempat pembuangan sampah terpadu ini terletak di kecamatan Bantargebang, dimana Bantargebang ini memiliki lahan seluas 110 Ha, yang 
sebagian besar lahan digunakan untuk menampung berbagai jenis sampah dan sekitar 20\% lahannya digunakan untuk fasilitas umum lainnya seperti kantor dan taman-taman, namun ini menjadi kelemahan kita TPA-nya hanya satu dan semua sampah dibuang ke TPA Bantargebang ini, tetap saja jika sampah tidak dibuang ke TPA ini, lalu akan dibuang ke tempat pembuangan akhir mana lagi? Ini menjadi tantangan bagi kita.” (wawancara Tanggal 7 Agustus 2019 pukul 11.05 WIB).

Melakukan kerjasama pun harus memiliki sebuah payung hukum dan di dalam Perjanjian itu juga mengatur secara rinci tentang besaran bantuan dana kompensasi yang harus diberikan Pemprov DKI Jakarta kepada Pemkot Bekasi. Hal ini seperti yang disampaikan oleh Kepala Sub Bagian Tata Usaha UPST DLH DKI Jakarta, yaitu "Payung hukumnya tentu PKS itu. Didalamnya ada bantuan keuangan, untuk daerah penyangga di Jabodetabek dan yang paling besar adalah Kota Bekasi, karena di disitu ada bantargebangnya. Bantuan keuangan berupa kompensasi, bantuan pelestarian lingkungan hidup, bantuan pendidikan, sosial, kesehatan, dan bantuan langsung tunai, intinya bantuan yang nantinya yang mungkin berdampak pada warga sekitar dan harus ditanggulangi." (wawancara Tanggal 7 Agustus 2019 pukul 11.05 WIB). Dana kompensasi diperuntukkan khusus oleh Pemprov DKI Jakarta kepada Kecamatan Bantargebang melalui Pemkot Bekasi, untuk pemanfaatan lahan TPST Bantargebang. Hal ini serupa seperti yang disampaikan oleh Kepala Sub Bagian Tata Usaha UPST DLH DKI Jakarta, yaitu "Inti dari isi PKS adalah hak dan kewajiban dari masing-masing pemerintah daerah yang tentunya semuanya saling menguntungkan, salah satunya ada rumusan bantuan besarnya dana kompensasi untuk Kota Bekasi, bantuan keuangan kemitraan. Khusus kerjasama dengan Kota Bekasi, kami memiliki dua bantuan. Bantuan kemitraan untuk peningkatan fasilitas umum antara Jakarta dan Bekasi, sedangkan bantuan kompensasi itu untuk menanggulangi dampak yang dikhususkan dari TPST Bantargebang. Jadi dari total 12 kecamatan yang ada di Bekasi, hanya satu kecamatan saja yang mendapatkan dana kompensasi yaitu kecamatan Bantargebang. Terdapat empat kelurahan, tiga kelurahan mendapatkan bantuan langsung tunai. Lalu salah satu isi PKS selanjutnya adalah lebih kepada penyelesaian sengketa, monitoring dan evaluasi dari PKS itu sendiri. PKS tidak setiap tahun berubah. Addendum/ perubahan berlaku sesuai kondisi pada saat itu. Jadi kita harus membedakan dana kemitraan dan dana kompensasi. Dana kemitraan tidak ada hitung-hitungannya, artinya dana kemitraan yang diajukan oleh Pemerintah Kota Bekasi melalui proposal pengajuan tidak sepenuhnya disetujui oleh Pemerintah Provinsi jika memang terdapat hal-hal yang tidak direstui oleh pihak Pemerintah Provinsi DKI Jakarta. Nah, jika untuk dana kompensasi, semua itu sudah ada rumusnya di PKS yang sudah disetujui oleh kedua belah pihak.” (wawancara Tanggal 7 Agustus 2019 pukul 11.05 WIB).

Peran masyarakat dalam pelestarian lingkungan dan pencegahan bencana dalam kasus ini adalah dengan melakukan diet sampah, selain itu dengan membuang sampah pada tempat nya dan tidak disembarang tempat merupakan salah satu hal untuk melestarikan lingkungan. Selain itu dengan mendaur ulang sampah pun merupakan salah satu aspek dalam pelestarian lingkungan dan meminimalisir bencana, mengingat gunungan sampah yang ada di TPST Bantargebang yang kian hari kian meningkat, dengan mendaur ulang sampah pun merupakan hal kecil dalam melestarikan lingkungan, dengan mendaur ulang sampah pun akan membuka lapangan bisnis yang menjanjikan.

Peran akademisi dalam pelestarian lingkungan dan pencegahan bencana yang ditimbulkan dari sampah adalah dengan melakukan sosialisasi bagaimana sulitnya beberapa bahan sampah untuk diuraikan, melakukan pelatihan dalam mendaur ulang sampah dan membuka lapangan bisnis untuk akademisi dan melakukan sosialisasi ke masyarakat terkait sampah-sampah yang ada. Melakukan gerakan diet sampah guna menyadarkan masyarakat bahwa banyak bahan yang dapat digunakan kembali dan tidak hanya sekali pakai.

Belum adanya peran swasta dalam kasus ini bisa jadi merupakan salah satu faktor yang menyebabkan sulitnya pemerintah dalam mengelola sampah di TPST Bantar gebang dan sulitnya pula melakukan kelestarian lingkungan dan pencegahan bencana yang ditimbulkan oleh sampah.

\section{KESIMPULAN}

Kerjasama yang dilakukan dalam pengelolaan sampah di TPST Bantargebang Bekasi, diawali dengan membuat sebuah dasar hukum, yang kini tertuang dalam kerjasama antara Pemerintah Provinsi Daerah Khusus Ibukota Jakarta dengan Pemerintah Kota Bekasi Nomor 96 Tahun 1999 dan Nomor 168 Tahun 1999 tentang pengelolaan sampah dan Tempat Pembuangan Akhir (TPA) sampah di Kecamatan Bantar Gebang, Kota Bekasi dan perjanjian perubahan (addendum) perjanjian kerjasama antara Pemerintah Provinsi DKI Jakarta dengan Pemerintah Kota Bekasi tentang Peningkatan Pemanfaatan Lahan Tempat Pembuangan Akhir (TPA) Sampah menjadi Tempat Pengelolaan Sampah Terpadu (TPST) Bantargebang Kota Bekasi No. 4 Tahun 2017 dan No. 224 Tahun 2017. Kemudian, Pemerintah Provinsi DKI Jakarta dan Pemerintah Kota Bekasi untuk mengimplementasikan kebijakan dan pemenuhan sumber-sumber terkait dalam pelaksanaan program sudah dilakukan contohnya dengan melakukan sebuah sosialisasi kepada masyarakat DKI Jakarta terkait program yang akan dilakukan yaitu pengurangan sampah. Selain itu, Respon Pemerintah Provinsi DKI Jakarta dalam pengelolaan sampah di TPST Bantargebang ini dengan memberikan bantuan keuangan atau dana kemitraan dan dana kompensasi kepada Pemerintah Kota Bekasi, bantuan ini bersifat wajib.

Penulis menemukan, bahwasannya Informasi yang dilakukan Pemerintah untuk wilayah Bantargebang adalah satu-satunya wilayah yang saat ini digunakan sebagai penampungan sampah dan belum ada wilayah yang lain sebagai 
pengganti TPST Bantargebang. Melalui konteks Sumber Daya dalam teori Edward, dalam segi anggaran untuk pengelolaan TPST ini didapatkan dari penerimaan pembayaran atas pembuangan sampah Pihak Kedua berdasarkan kesepakatan para pihak, menerima usulan proposal atau kegiatan bantuan keuangan dari pihak kedua terkait dengan dana kompensasi pengelolaan TPST Bantargebang Kota Bekasi, menerima laporan pertanggung jawaban dari Pihak Kedua atas pelaksanaan program/kegiatan bantuan keuangan terkait dana kompensasi pengelolaan TPST Bantargebang Kota Bekasi sesuai dengan peraturan perundang-undangan, karena dalam teori Edward III konteks sumber daya berisikan pula tentang kewenangan apa saja yang berhak ada dan persetujuan kedua belah pihak, kewenangan tersebut pun sudah ada dalam Addendum TPST Bantargebang.

Respon Pemerintah Provinsi merumuskan tiga Kegiatan Strategi Daerah (KSD) untuk mengatasi permasalahan pengelolaan sampah jangka pendek maupun jangka panjang. Tiga KSD itu meliputi Pengurangan sampah di Sumber, Optimalisasi TPST Bantargebang, Pembangunan Intermediate Treatment Facility (ITF). Pada program optimalisasi TPST Bantargebang Pemerintah Provinsi DKI Jakarta bekerja sama dengan Badan Pengkajian dan Penerapan Teknologi (BPPT) membangun Pembangkit Listrik Tenaga Sampah (PLTSa) yang sekarang sudah beroperasi. Pengolahan sampah dengan teknologi termal ini menggunakan sampah lama dari landfill (landfill mining) untuk dijadikan bahan bakar alternatif (Refused Derived Fuel) industri semen. Bahan bakar alternatif dari sampah ini setara dengan nilai kalor batubara muda. Pada program Pembangunan Intermediate Treatment Facility (ITF) adanya ITF TPST Bantargebang hanya akan menampung residu pengolahan sampah di dalam kota.

Implementasi pelestarian lingkungan dan pencegahan bencana menggunakan konsep collaborative governance yang dilakukan Pemerintah Provinsi DKI Jakarta dan Pemerintah Kota Bekasi salah satunya fasilitas-fasilitas yang ada pada TPST Bantar Gebang setidaknya lebih diperbanyak dan lebih dipenuhi. Dalam konsep collaborative governance ada pula peran akademisi dan peran swasta, namun sayangnya belum ada kerjasama swasta dalam pengelolaan TPST Bantar Gebang, kerjasama dengan akademisi dalam pelestarian lingkungan dan pencegahan bencana yang ditimbulkan dari sampah adalah dengan melakukan sosialisasi bagaimana sulitnya beberapa bahan sampah untuk diuraikan, melakukan pelatihan dalam mendaur ulang sampah dan membuka lapangan bisnis untuk akademisi dan melakukan sosialisasi ke masyarakat terkait sampah-sampah yang ada.

\section{DAFTAR PUSTAKA}

Addendum, "Pemerintah DKI Jakarta dan Pemerintah Kota Bekasi.2009. Perjanjian Kerjasama Antara Pemerintah Provinsi DKI Jakarta dengan Pemerintah Kota Bekasi Nomor 4 Tahun 2009 Peningkatan Pemanfaatan Lahan Tempat Pembuangan Akhir (TPA) Sampah Menjadi Pengolahan Sampah Terpadu (TPST) Bantargebang Kota Bekasi”, 2009.

Addendum, "Pemerintah DKI Jakarta dan Pemerintah Kota Bekasi. 2009. Perjanjian Kerjasama Antara Pemerintah Provinsi DKI Jakarta dengan Pemerintah Kota Bekasi Nomor 71 Tahun 2009 Peningkatan Pemanfaatan Lahan Tempat Pembuangan Akhir (TPA) Sampah Menjadi Pengolahan Sampah Terpadu (TPST) Bantargebang Kota Bekasi”, 2009.

Addendum, "Pemerintah DKI Jakarta dan Pemerintah Kota Bekasi. 2016. Perjanjian Perubahan (Addendum) Perjanjian Kerjasama Antara Pemerintah Provinsi DKI Jakarta dengan Pemerintah Kota Bekasi Nomor 25 Tahun 2016 Peningkatan Pemanfaatan Lahan Tempat Pembuangan Akhir (TPA) Sampah Menjadi Pengolahan Sampah Terpadu (TPST) Bantargebang Kota Bekasi”, 2016.

Addendum, "Pemerintah DKI Jakarta dan Pemerintah Kota Bekasi. 2016. Perjanjian Perubahan (Addendum) Perjanjian Kerjasama Antara Pemerintah Provinsi DKI Jakarta dengan Pemerintah Kota Bekasi Nomor 444 Tahun 2016 Peningkatan Pemanfaatan Lahan Tempat Pembuangan Akhir (TPA) Sampah Menjadi Pengolahan Sampah Terpadu (TPST) Bantargebang Kota Bekasi”, 2016.

Addendum, "Pemerintah DKI Jakarta dan Pemerintah Kota Bekasi. 2017. Perjanjian Kerjasama Antara Pemerintah Provinsi DKI Jakarta dengan Pemerintah Kota Bekasi Nomor 4 Tahun 2017 Peningkatan Pemanfaatan Lahan Tempat Pembuangan Akhir (TPA) Sampah Menjadi Pengolahan Sampah Terpadu (TPST) Bantargebang Kota Bekasi”, 2017.

Addendum, "Pemerintah DKI Jakarta dan Pemerintah Kota Bekasi. 2017. Perjanjian Perubahan (Addendum) Perjanjian Kerjasama Antara Pemerintah Provinsi DKI Jakarta dengan Pemerintah Kota Bekasi Nomor 224 Tahun 2017 Peningkatan Pemanfaatan Lahan Tempat Pembuangan Akhir (TPA) Sampah Menjadi Pengolahan Sampah Terpadu (TPST) Bantargebang Kota Bekasi”, 2017.

Kholilurrohman, H., Adiyasha, D., Tanriajeng, N., (2019, November), Kerja sama Antara Pemerintah DKI Jakarta dan Pemerintah Kota Bekasi dalam Mengelola TPST Bantar Gebang. Paper dipresentasikan di Temu Admi 2019 Universitas Negeri Sebelas Maret Surakarta. 
Pratikno. 2007. Kerja sama antar Daerah, Kompleksitas, dan Tawaran Kelembagaan. Yogyakarta: UGM.

Suranto, G. (2019, 24 Februari). "Pemprov DKI Jakarta ajak seluruh pihak wujudkan Jakarta bebas sampah”. Infopublik. id. Diakses dari https://www.infopublik.id/sosial-budaya/329137/pemprov-dki-ajak-seluruh-pihak-wujudkanJakarta-bebas-sampah.

Winahyu, D,. Hartoyo, S,. Syaukat, Y., (2013) Strategi Pengelolaan Sampah pada Tempat Pembuangan Akhir Bantargebang, Bekasi. 